\title{
Cell Elongation in the Grass Pulvinus in Response to Geotropic Stimulation and Auxin Application
}

\author{
P. Dayanandan, Frederick V. Hebard, and Peter B. Kaufman \\ Department of Botany, University of Michigan, Ann Arbor, MI 48109, USA
}

\begin{abstract}
Summary. Horizontally-placed segments of Avena sativa $\mathrm{L}$. shoots show a negative geotropic response after a period of $30 \mathrm{~min}$. This response is based on cell elongation on the lower side of the leaf-sheath base (pulvinus). Triticum aestivum L., Hordeum vulgare L. and Secale cereale L. also show geotropic responses that are similar to those in Avena shoots. The pulvinus is a highly specialized organ with radial symmetry and is made up of epidermal, vascular, parenchymatous and collenchymatous tissues. Statoliths, which are confined to parenchyma cells around the vascular bundles, sediment towards the gravitational field within 10-15 min of geotropic stimulation. Collenchymatous cells occur as prominent bundle caps, and in Avena, they occupy about $30 \%$ of the volume of the pulvinus. Geotropic stimulation causes a 3- to 5-fold increase in the length of the cells on the side nearest to the center of the gravitational field. Growth can also be initiated in vertically-held pulvini by the application of indole-3-acetic acid, 1-naphthaleneacetic acid or 2.4-dichlorophenoxyacetic acid. 2.3.5-triiodobenzoic acid interferes with growth response produced by geotropic stimulation as well as with the response caused by auxin application. Gibberellic acid and kinetin have no visible effect on the growth of the pulvinus. Polarization microscopy shows a unique, non-uniform stretching of the elongating collenchymatous cells. Nonelongated collenchymatous cells appear uniformally anisotropic. After geotropic stimulation or auxin application, they appear alternately anisotropic and almost isotropic. Such a pattern of cell elongation is also observed in collenchyma cells of geotropically-stimulated shoots of Rumex acetosa L., a dicotyledon.
\end{abstract}

Abbreviations: $2.4-\mathrm{D}=2.4$-dichlorophenoxyacetic acid; $\mathrm{GA}_{3}=$ gibberellic acid; IAA $=$ indole-3-acetic acid; NAA $=1$-naphthaleneacetic acid; TIBA $=2.3 .5$-triiodobenzoic acid

\section{Introduction}

If the stem (or a stem segment containing a node) of a grass is placed horizontally, the base of the leaf sheath immediately above a node will, in most species, grow on the side of the outer epidermis which is towards the gravitational field, resulting in an upward curvature of the stem. The leaf-sheath base, called pulvinus, is a feature common in most members of the sub-family Festucoideae. Many other grasses, primarily members of the sub-family Panicoideae, either lack leaf-sheath pulvini or possess poorly developed ones, but have specialized regions at the bases of the internodes which are sensitive to geotropic stimulation (Brown et al., 1959).

The nature of the georesponse of the leaf-sheath pulvinus, and the possibility of hormonal control of this response, were investigated by Sachs (1887, p. 687-689), Arslan and Bennet-Clark (1960), Maeda (1958) and Bridges and Wilkins (1973). This paper is a report on the nature of the geotropic response in sheath pulvini, the effects of several hormones on the pulvini, and the striking response of the collenchymatous cells in the pulvini to geostimulation and to application of IAA, NAA and 2,4-D.

\section{Materials and Methods \\ Most of the work reported herein was carried out on Avena sativa L. cv. Victory (Swedish Seed Association, Svalöf, Sweden). Howev- er, for comparative studies, the following grasses which possess sheath pulvini were also employed: Hordeum vulgare L. cv. Larker, Triticum aestivum L. cv. Sonia, Secale cereale L. cv. Wheeler, Oryza sativa L. cv. Colusa, O. glaberrima Steud., Poa pratensis L., Festuca rubra L., Leersia oryzoides (L.) Swartz., Muhlenbergia schreberi Gmel. and Panicum sp. Seeds of Hordeum, Triticum and Secale were obtained from the Agricultural Research Service, U.S. Department of Agriculture, Beltsville, MD, USA, and the two species of Oryza from the Department of Agronomy of the Univer- sity of California, Davis. The remaining grasses were collected from the field in the vicinity of Ann Arbor. Reed grass (Phragmites}



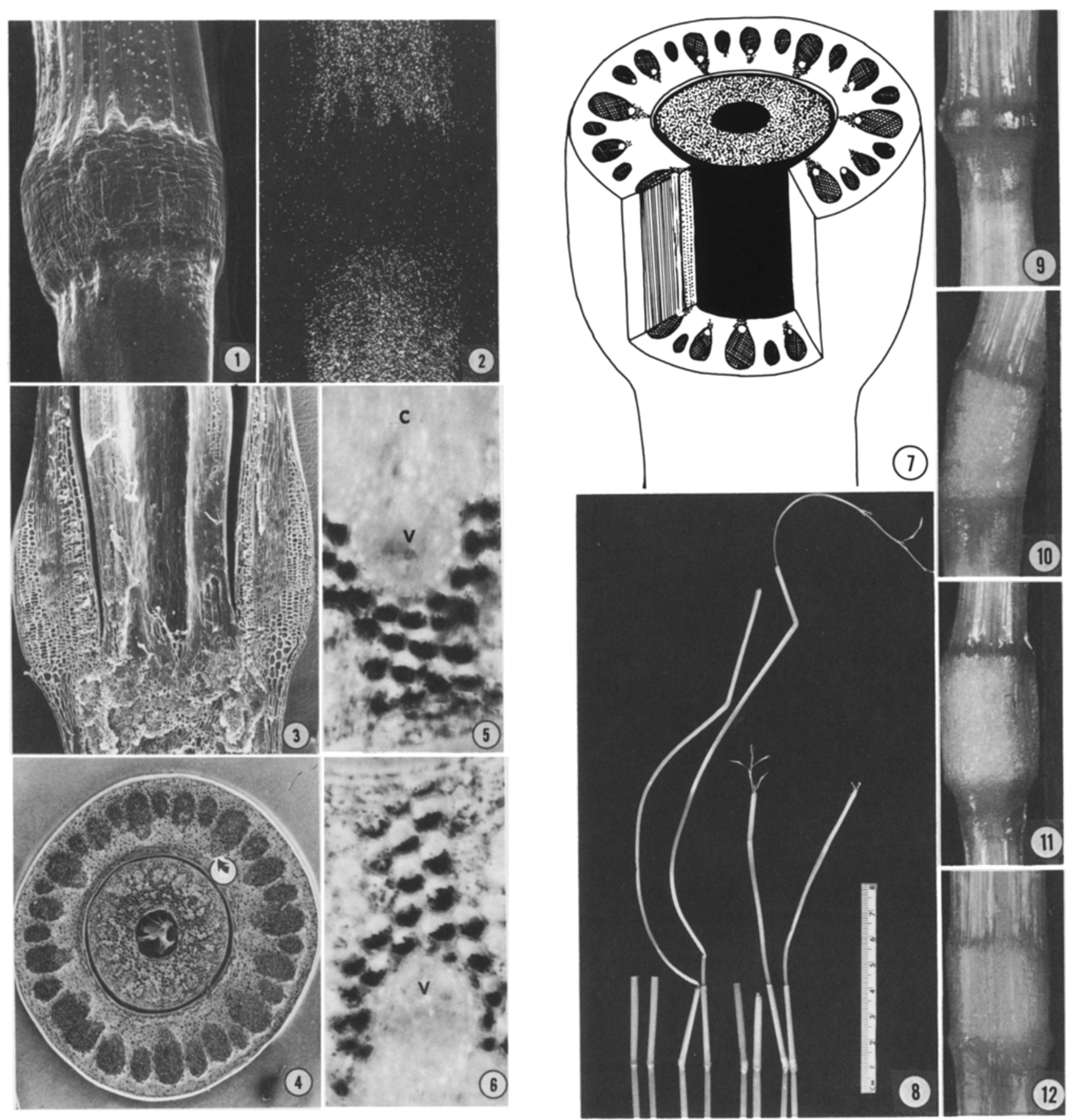

Figs. 1 and 2. Scanning electron micrographs of node-pulvinus region in Muhlenbergia schreberi. Fig. 1 is a secondary electron image that shows the swollen basal leaf-sheath pulvinus. Fig. 2 is an X-ray image of silicon as it is distributed on the areas in Figure 1. Silicon is distributed as silica in specialized silica cells or over the entire epidermal wall surface only on the leaf sheath above and the internode below the pulvinus. Both $\times 30$

Fig. 3. Longitudinal section through the node and pulvinus of Secale cereale. The elongated cells in the pulvinus are collenchymatous, and they are lignified immediately above and below the pulvinus. Scanning electron micrograph made from a critical point dried preparation. $\times 35$

Fig. 4. Scanning electron-microscope view of a cross section passing through a pulvinus in Avena sativa. The central hollow cylinder is the internode. Prominent bundle capsive collenchymatous cells are seen in three different sizes in the pulvinus. Arrow points to

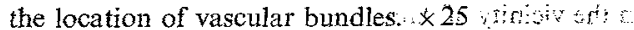


australis (Cav.) Steudel), which possesses a poorly-developed leafsheath pulvinus and a well-developed geo-sensitive region in its internode base, was also used to study the nature and response of the collenchymatous cells of these regions. Reed grass was collected from fields near Ann Arbor. For a comparative study of the collenchyma of a dicotyledon, garden sorrel (Rumex acetosa L.) plants were used. These were grown from the seed collection of the University of Michigan Matthaei Botanical Gardens. Oat, wheat, rye, barley and rice plants were grown in a greenhouse, and the geotropic response of the pulvini below their peduncular nodes was studied at the stage when their inflorescences were about to emerge; the oat plants were 50 days old at this stage.

In the work with grasses, excised segments with $3-5 \mathrm{~cm}$ of shoot on either side of a pulvinus were laid horizontally on filter paper in flat-bottomed plexiglas trays containing $0.1 \mathrm{M}$ sucrose. One side of the shoots was uniformly weighed down by rectangular glass plates. Vertically-held segments with their bases immersed in $0.1 \mathrm{M}$ sucrose were gently scratched at their pulvini to break some of the epidermal cells and were treated with IAA (1\%), NAA $(0.2 \%), 2,4-\mathrm{D}(0.2 \%), \mathrm{GA}_{3}(1 \%)$, kinetin $(1 \%)$ and TIBA $(1 \%)$, all in lanolin (weight percent). Incubation was in a dark chamber at $28^{\circ}$. Early and continuous responses of the shoots were also observed with time lapse-photography and angular position transducers (Metripack. \#33-06, Gould, Inc., Cleveland, $\mathrm{OH}$, USA) that translate displacements $\geqq 0.01^{\circ}$ to a 10 -inch full-scale movement of a recorder pen.

Morphology and anatomy of the pulvini were studied with light and scanning electron microscopes. Wax-embedded microtome sections and cells macerated in $1 \mathrm{~N} \mathrm{HCl}$ at $80^{\circ}$ were stained in Congo red, $\mathrm{I}_{2} \mathrm{KI}$ followed by $\mathrm{H}_{2} \mathrm{SO}_{4}$, chlor-zinc-iodide, phloroglucinol, ruthenium red and the hydroxylamine ferric chloride reaction for pectic substances (Jensen, 1962). Preparations were examined with a phase-contrast microscope and a microscope equipped with crossed polarizers and a 1st order Red Plate. Intact or sectioned material was critical-point-dried and examined with a scanning electron microscope (Japan Electron Optics Lab., model JSMU3) equipped with X-ray analyser attachments.

\section{Results}

The pulvinus completely surrounds the internode, and in oat plants, is $1-2 \mathrm{~mm}$ long (Figs. 7, 9). This length can vary if growth has occurred due to geotropic stimulation in the field or greenhouse. Externally, the epidermis over the pulvinus in many grasses is easily distinguishable from that of the internode below and the leaf sheath above by a lack of trichomes, corksilica cells and stomata. Even when some hairs and silica cells are found in this region (as in Leersia oryzoides), the extent of silicification of the entire surface of the pulvinus is remarkably low compared with the internode below and the leaf-sheath above (Figs. 1, 2). No silicification occurs during or after the elongation of these epidermal cells in response to gravitational stimulus.

As seen in the cross-sections (Figs. 4, 7), the pulvinus is made up of external and internal epidermis, parenchyma, collenchymatous and vascular tissues. About 30 collenchymatous bundle caps run the entire length of the pulvinus mostly as unbranched strands (Fig. 7). Calculations made from serial sections indicate that the collenchymatous tissue occupies $30 \%$ of the volume of the pulvinus. Above the pulvinus, the collenchymatous cells intergrade with lignified sclerenchyma which occupy a more peripheral position in the leaf sheath; below the pulvinus, they become lignified as they merge with the cells of the nodal plate (Figs. 3, 13).

Figs. 5 and 6. Cross section of pulvinus from an Avena segment which had been laid horizontally for one hour. Light micrographs made from sections stained with $\mathrm{I}_{2} \mathrm{KI}$ to show the statoliths. Fig. 5 shows a region from the upper half of the horizontally-laid pulvinus. The statoliths have fallen to the morpholically lower surface of the statocytes in this region. However, this region does not show any growth response. Fig. 6, from the lower half of the horizontally-held pulvinus shows statolith sedimentation to the sides which are associated with the cells that elongate. $v=$ vascular bundle; $c=$ collenchymatous bundle cap. Both $\times 240$

Fig. 7. Diagrammatic reconstruction of the node-pulvinus region in Avena. The central hollow cylinder is the base of the internode. The region of the internode shown here possesses intercalary meristematic activity and is highly responsive to GA $\mathrm{A}_{3}$. The pulvinus has prominent collenchymatous bundle caps and associated vascular bundles (white areas) and statocytes (stippled areas). The entire pulvinus is responsive to IAA. $\times 18$

Fig. 8. Pairs of Avena segments that were held vertically and treated as follows with direct application of lanolin to the pulvini: from left to right, first pair, lanolin control; second pair, $\mathrm{GA}_{3}$; third pair, IAA and fourth pair, $\mathrm{GA}_{3}+$ IAA. Photographed after 3 days of treatment. The internode elongated in response to $\mathrm{GA}_{3}$, and IAA interfered with this response. The pulvinus responded to IAA only. $\times 0.5$

Figs. 9-12. Figs. 9-10. Response of segments to alternate geostimulation and growth substances. $\times 5$. Fig. 9. A control segment. Fig. 10. The pulvinus has grown in response to alternate geostimulation of the opposite sides. Horizontally placed segment was turned $180^{\circ}$ every $24 \mathrm{~h}$ for 4 days. Fig. 11. Growth of pulvinus in response to uniform application of IAA all around a vertically-held segment. 4 days old. Fig. 12. Growth of pulvinus in response to uniform application of IAA $+\mathrm{GA}_{3}$ all around the pulvinus on a vertically-held segment. This treatment also causes internodal elongation 
All parenchyma cells of the pulvinus possess plastids. However, only those parenchyma cells located around the vascular bundles appear to function as statocytes (Figs. 5-7). Only their plastids, about 30 60 per cell, stain deeply with $\mathrm{I}_{2} \mathrm{KI}$ and sediment towards the center of the gravitational field. This general pattern of a grass pulvinus with strands of nonlignified collenchymatous cells and statolith-containing cells around the vascular bundles is found in every one of the grasses possessing sheath pulvini that we have examined. Collenchymatous cells and statocytes are also found in the specialized geosensitive region at the internode base in Phragmites australis.

When a segment of Avena is held horizontally, a negative geotropic response occurs about $30 \mathrm{~min}$ after placing in the horizontal position. Segments of wheat behave similarly whereas those of barley respond even as early as $15 \mathrm{~min}$. (Bridges and Wilkins,

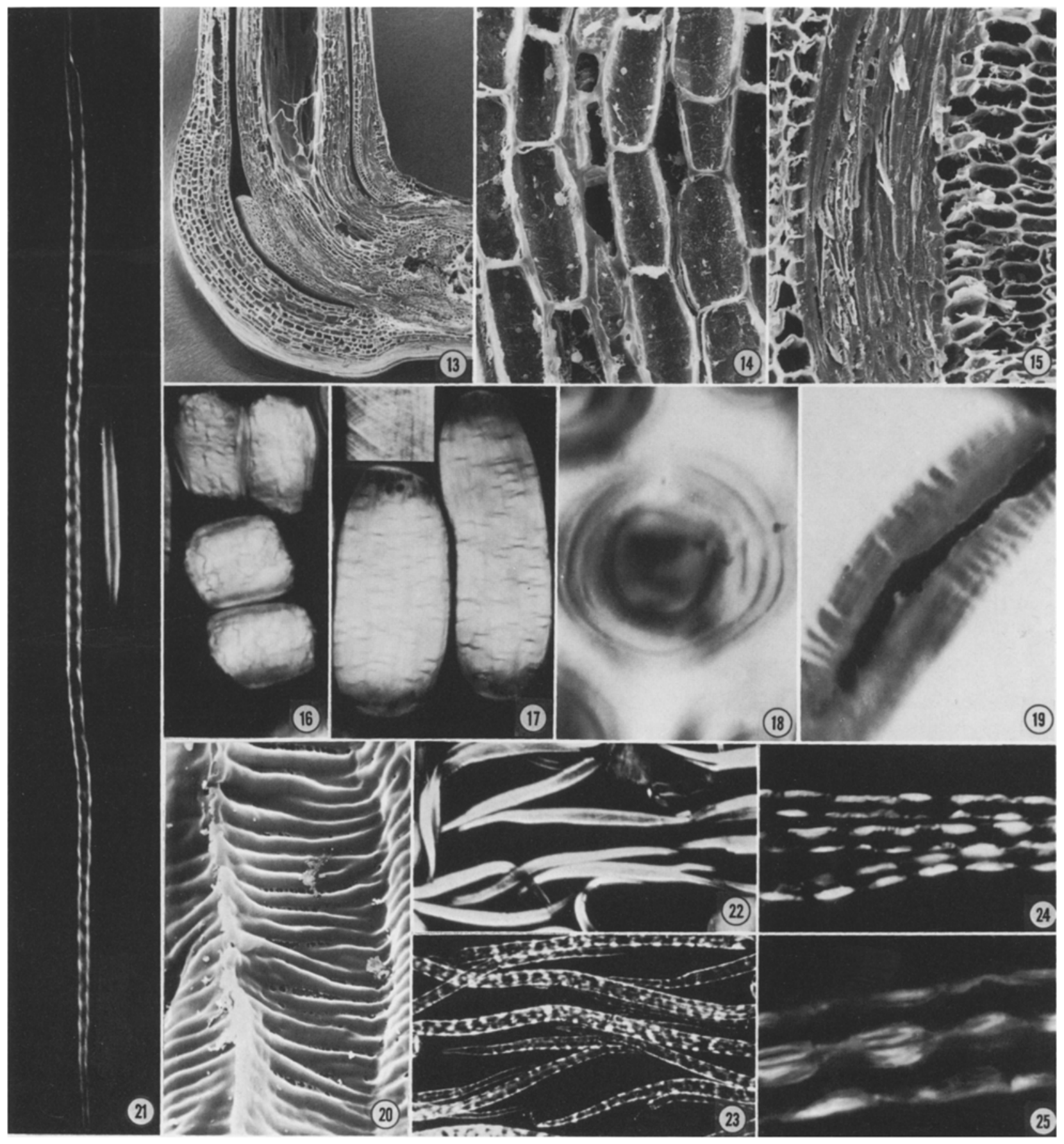




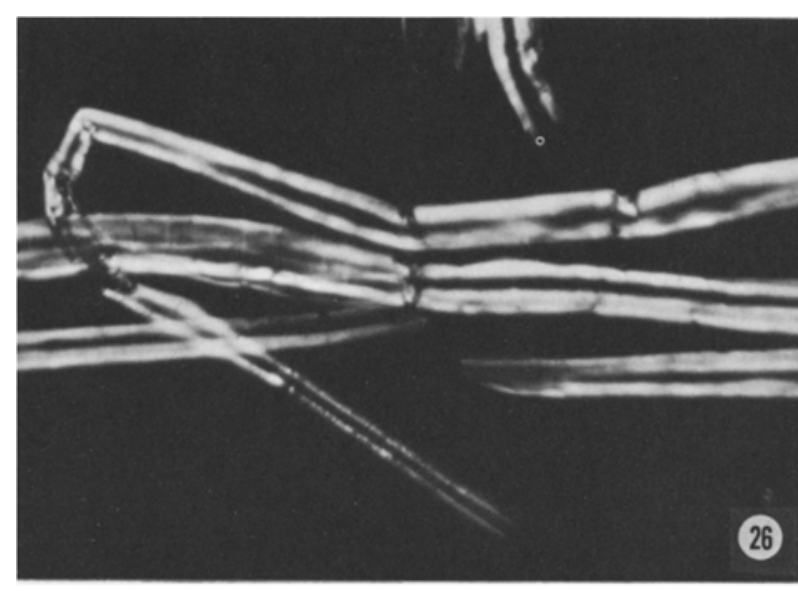

Fig. 26. Collenchyma cells of a dicotyledon, isolated from an unelongated side of young stem of Rumex acetosa. Photographed between crossed polarizers. $\times 190$

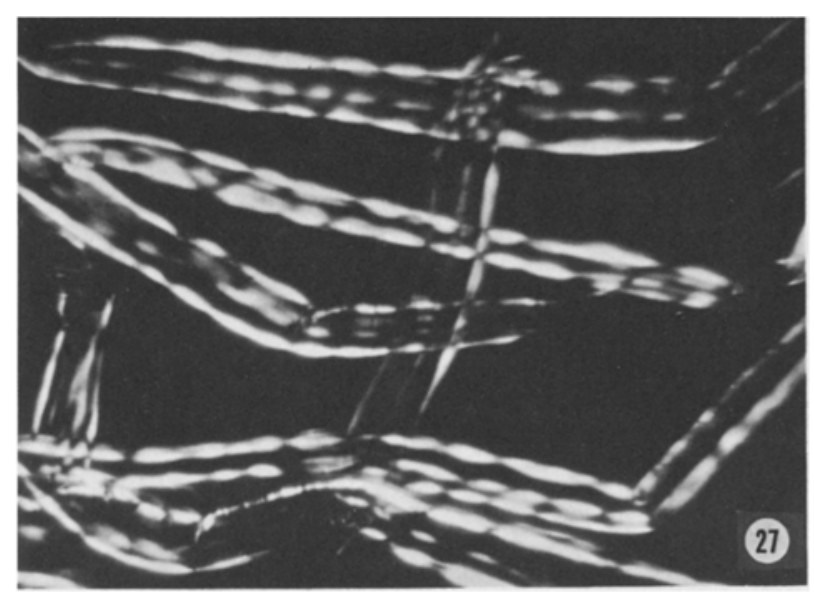

Fig. 27. Collenchyma cells of Rumex acetosa isolated from that portion of a stem that has elongated in response to natural geostimulation. The stretching patterns, as seen between crossed polarizers, are very similar to those of collenchymatous cells from pulvini of grasses. $\times 190$

directed downwards, results in cell elongation only on this side. Such alternate reversions 4 times in 4 days) can result in a pulvinus that has grown 4 times longer than the control (Fig. 10). Uniform application (all around the pulvinus) of TIBA to horizontally-held segments inhibits the geotropic growth response, whereas IAA, NAA and 2,4-D decrease the bending response by initiating some growth on the upper side as well.

Application of IAA, NAA or 2,4-D all around the pulvinus of vertically-held segments results in uniform growth by cell elongation (Fig. 11). Unilateral

Fig. 13. Muhlenbergia sp. Scanning electron micrograph of a longitudinal section of a segment that has bent almost $90^{\circ}$. Besides the internode and the pulvinus, an axillary bud is also seen on the elongated side. $\times 30$

Figs. 14 and 15. Scanning electron micrographs of identical magnification taken from the elongated and constricted sides, respectively, of the specimen shown in Figure 13. Note the thickness of the parenchyma cell walls and the horizontal thickenings of the collenchymatous cells in the constricted region. $\times 290$

Figs. 16-25. Avena sativa. Figs. 16 and 17. Parenchyma cells before and after 3 days of growth in response to geostimulation. Pits are seen at right angles to the long axis of the cell. (The insert in Figure 17 was stained with Congo red and shows the orientation of microfibrils in an elongated cell.) Faintly visible longitudinal ribs represent regions where cellulose microfibrils run parallel to the long axis. All pictures taken with crossed polarizers. Figures 16 and $17 \times 460$, insert $\times 1,070$. Fig. 18. Cross section of a collenchymatous cell stained to show cellulose rich layers (darkly stained) alternating with pectin rich layers. Photographed between crossed polarizers $\times 1,550$. Fig. 19. Isolated collenchymatous cell stained with iodine $-\mathrm{H}_{2} \mathrm{SO}_{4}$ and photographed between crossed polarizers. Darkly stained cellulose-rich layers alternate with light pectin-rich regions. Such lamellations are visible both longitudinally and horizontally. $\times 1,860$. Fig. 20. Scanning electron microscopic view of the horizontal bars of a collenchymatous cell. This preparation was made from a critical-pointdried section. The thick bars represent cellulose rich regions. $\times 4,415$. Fig. 21 . Isolated collenchymatous cell from a 2 day geostimulated pulvinus compared with a cell from an unstimulated control segment. Both preparations photographed in cross-polarized light. $\times 135$. Fig. 22. Isolated collenchymatous cells from a control pulvinus viewed between crossed polarizers. The cells are uniformly birefringent and the walls are uniformly thick $\times 135$. Fig. 23. Isolated collenchymatous cells from a pulvinus that has grown in response to $24 \mathrm{~h}$ geostimulation. As seen between crossed polarizers, regions that have stretched appear thin and almost isotropic whereas the unstretched regions remain as thick as in control cells and are birefringent. $\times 135$. Figs. 24 and 25 . Collenchymatous cells isolated from pulvini that were treated with IAA for 3 days. Photographed between crossed polarizers. Thick and thin-stretched regions of adjacent cells lie next to each other. Horizontal and longitudinal lamellations are also visible. Figure $24, \times 430$. Figure $25, \times 1,285$ 
application of these auxins results in bending away from the side of application. However, the curvatures developed seldom exceed one-half of those developed in response to gravitational stimulation for a comparable duration of time. Segments can also be split lengthwise into two halves and freed from internodal tissues to study their responses to gravity and auxin application. Split segments placed horizontally, so as to keep the intact outer epidermis of the pulvinus lie towards the gravitational field, show a negative geotropic response resulting in curvatures averaging $50^{\circ}$ after $24 \mathrm{~h}$ geostimulation. Unilateral application of IAA on the intact outer surface of the pulvini of vertically-held split segments results in curvatures that average $48^{\circ}$ after $24 \mathrm{~h}$, which does not significantly differ from the geostimulated response.

$\mathrm{GA}_{3}$, kinetin, or TIBA has no effect on growth of the pulvinus of vertically-held segments. Simultaneous application of IAA and TIBA in various concentrations either diminishes or completely depresses the growth response achieved by the application of IAA alone. While $\mathrm{GA}_{3}$ seems to have no effect upon the growth of the pulvinus, either alone or in combination with IAA, it has a remarkable growth-promoting effect on young, elongating internodes that are contained within the pulvini (Kaufman, 1965, 1967). With simultaneous application of IAA and $\mathrm{GA}_{3}$ to the pulvinus, the pulvinus grows in response to the IAA, and the internode grows in response to the $\mathrm{GA}_{3}$ (Figs. 8, 12).

The nature of cell elongation induced by gravitational stimulus and by auxin application appear to be identical (Figs. 21-25). All cell types that make up the pulvinus, including the vascular elements, elongate. Two to three days of treatment result in the elongation of parenchyma and collenchymatous cells from an average length of 40 and $350 \mu \mathrm{m}$, respectively, to 170 and $1,600 \mu \mathrm{m}$, respectively (Figs. 16, 17, 21). The diameter of the collenchymatous cells (about $13 \mu \mathrm{m}$ in control segments) changes very little after elongation. In control segments, the parenchyma cells of the pulvinus are negatively birefringent while the collenchymatous cells are positively birefringent. The sign of birefringence of these cells does not change after elongation. Such observations were made, however, on entire cells with both cell walls flattened between the slide and cover slip. Observation between crossed polarizers of elongated parenchyma stained with Congo red show that the microfibrils in many layers are reoriented to assume a flatter helix compared with the more transverse orientation in the nonelongated cells (see insert in Fig. 17).

The collenchymatous cells of nonelongated grass pulvini are uniformally thickened, and lack intercellular spaces. In cross-section, the wall is found to be alternately rich in cellulose (but poor in pectin) and pectin (but poor in cellulose) (Fig. 18). As many as 20 such cellulose-rich layers were counted; these layers are also visible in optical longisections of isolated cells (Fig. 19). Such alternating layers in collenchyma cells of dicotyledons are well-documented (Majumdar and Preston, 1942; Beer and Setterfield, 1958; Roland, 1966; Wardrop, 1969). Isolated collenchymatous cells of grass pulvini also show a series of transverse bands, about $1 \mu \mathrm{m}$ apart, that appear to run from the periphery towards the lumen of the cells (Fig. 19). In unstained material, these bands can be seen only when viewed between crossed polarizers. Histochemical reactions show these bands as alternating arrangements of cellulose-rich and pectin-rich regions. In critical-point-dried collenchymatous cells, the pectin-rich regions appear thin, while the cellulose-rich regions appear as thick horizontal bars (Fig. 20).

Isolated collenchymatous cells from unstimulated pulvini appear uniformally birefringent between crossed polarizers (Figs. 21, 22). Elongated collenchymatous cells, on the other hand, show regions that are alternately anisotropic and almost isotropic (Figs. 21, 23-25). The isotropic regions are thinner, while the anisotropic regions are thicker. The thickness of the latter, about $1.0-1.5 \mu \mathrm{m}$, is comparable to the thickness of wall in unelongated cells. The thick and thin regions of adjacent cells often appear to lie next to each other (Figs. 24, 25). The abovementioned elongation pattern of collenchymatous cells is found in geostimulated and auxin-treated pulvini, and also in pulvini that have grown naturally in the greenhouse in response to displacement of the shoot from the vertical position.

\section{Discussion}

Three different regions of a grass shoot respond to gravitational stimuli resulting in growth. One of them is the well-studied response of coleoptiles in seedlings. The second involves the collar, the region connecting the leaf blade and the leaf sheath. This region, however, is atypical because the leaf blade always bends away from the shoot axis irrespective of the orientation of the shoot with respect to the gravitational field (Maeda, 1960). The third geosensitive region is the leaf-sheath pulvinus or the internodal base (Brown et al., 1959). The pulvinus and the internodal geosensitive region, as well as the collar between the leaf blade and the leaf sheath, have the following properties in common: they occupy a more or less intercalary position; their outer surfaces are poorly or not at all silicified in comparison with regions immediate- 
ly above and below them; they all have statolith-containing cells; and they possess unlignified collenchymatous cells. The structure of the collenchymatous cells of the bundle cap are very similar to the typical collenchyma cells of dicotyledons. The commom characteristics include the living nature of the cells, the presence of alternating layers of cellulose and pectin-rich layers and the presence of cross-lamellations as seen between crossed polarizers (Czaja, 1961).

Almost all previous studies of collenchymatous cells were concerned with material obtained from dicotyledonous plants (Anderson, 1927; Majumdar and Preston, 1941; Preston and Duckworth, 1946; Duchaigne, 1955; Roland, 1966; Wardrop, 1969). The lack of knowledge of collenchyma-like cells that occur in the monocotyledonous plants made it difficult to draw comparisons between typical collenchyma cells and those that occur in the geosensitive regions of grasses. Therefore, we have preferred to call the bundle-cap cells as collenchymatous, following the usage introduced by Esau (1967, p. 193).

As far as microscopic observations show, geotropic stimulation and auxin application elicit an identical elongation response in the cells that make up the pulvinus (Figs. 21-25). While auxins have been shown to cause growth of the pulvinus (Maeda, 1958; Arslan and Bennet-Clark, 1960), convincing evidence for the presence and role of IAA in the natural regulation of geotropic response in the grass pulvinus is not available (Bridges and Wilkins, 1973). The similarity of the response of the cells of the pulvinus to gravitational stimulation and auxin application further implicates auxin as a natural growth regulator in the grass pulvinus. The cell walls of the elongated epidermal cells and parenchyma cells are often thicker than the nonelongated cells (Figs. 14, 15). This indicates that cell-wall synthesis accompanies or succeeds elongation. The collenchymatous cells in all the grasses we have studied, however, always become thinner in selected regions after cell elongation (Figs. 21-25).

The stretching of the collenchymatous cells is unique and hitherto unreported. As already pointed out, the thin, stretched regions and the thick, unstretched regions often appear to lie next to each other (Figs. 24, 25). This indicates the mutual relation that may exist between adjacent cells; the thin, stretched regions, for example, may be locations where pit-pairs exist. If this is so, agent(s) responsible for localized wall loosening may have their immediate effect(s) at these sites. The thin, stretched regions might represent areas of special wall composition, or orientation, or both, that have responded to auxin. It is not known whether auxin binds to specific regions of the collenchymatous cells. The occurrence of stretched regions between unstretched regions pro- vides an opportunity to study this problem with autoradiographic techniques. In barley (whose response to gravitational stimulus among the grasses we have examined, is by far the most rapid and of the greatest magnitude, resulting in curvatures beyond $100^{\circ}$ ), and in rice, the thick and thin regions of elongating collenchymatous cells are clearly seen only during the first $24 \mathrm{~h}$ of growth. After this period, the entire cell appears to get thinner, uniformly. This indicates that the entire wall, or small areas distributed throughout the wall, is capable of responding to gravitational stimulus or to applied auxin.

The unique features of elongating collenchymatous cells offer a system the study of which may furnish important information about the events that occur in the cell wall during cell elongation. The behavior of the collenchymatous cells, as described above, is not unique to the pulvinus. Similar stretching patterns are observed in the collenchymatous cells in the collar regions that join the leaf blade and leaf sheath in Phragmites australis and in the collenchymatous cells that occur in the internodal geosensitive region of this grass. Of greater interest is the observation that naturally geostimulated shoots of a dicotyledon, Rumex acetosa, show similar stretching patterns of collenchyma cells that occur on the lower, elongated side (Figs. 26, 27).

While several workers have investigated the structure of collenchyma cells (Anderson, 1927; Majumdar and Preston, 1942; Beer and Setterfield, 1958; Roland, 1966; Wardrop, 1969), the knowledge gained from these studies is not adequate to offer an explanation for the stretching behavior of the collenchymatous cells. The transversly oriented bars that we have described here (Figs. 19, 20) exhibit a structural complexity that has not been resolved. These transverse bars are also found in several dicotyledons (Czaja, 1961). We are now investigating this region with the electron microscope to determine the cell wall structure and microfibril orientation before and after elongation.

This work was supported by grant BMS 75-16359 from National Science Foundation. We thank Professor Wilbur C. Bigelow and David Bay for their help and the University of Michigan Matthaei Botanical Gardens for growing the plants.

\section{References}

Anderson, D.B.: Über die Struktur der Kollenchymzellwand auf Grund mikrochemischer Untersuchungen. S.-B. Akad. Wiss. Wien, K1. Math. Naturwiss. 136, 429-439 (1927)

Arslan, N., Bennet-Clark, T.A.: Geotropic behaviour of grass nodes. J. exp. Bot. 11, 1-12 (1960) 
Beer, M., Setterfield, G.: Fine structure in thickened primary walls of collenchyma cells of celery peteoles. Amer. J. Bot. 45, 571$580(1958)$

Bridges, I.G., Wilkins, M.B.: Growth initiation in the geotropic response of the wheat node. Planta (Berl.) 112, 191-200 (1973)

Brown, W.V., Pratt, G.A., Mobley, H.M.: Grass morphology and systematics. II. The nodal pulvinus. Southw. Naturalist 4, 126130 (1959)

Czaja, A.T.: Neue Untersuchungen über die Struktur der partiellen Wandverdickungen von faserförmigen Kollenchymzellen. Planta (Berl.) 56, 109-124 (1961)

Duchaigne, A.: Les divers types de collenchymes chez les Dicotyledonés: leur ontogénie et leur lignification. Ann. Sci. nat., Bot., Sér. 11, 16, 455-479 (1955)

Esau, K.: Plant anatomy, 2nd edn. New York-London-Sydney: Wiley 1965

Jensen, W.A.: Botanical histochemistry. San Francisco-London: Freeman 1962

Kaufman, P.B.: The effects of growth substances on intercalary growth and cellular differentiation in developing internodes of Avena sativa. II. The effects of gibberellic acid. Physiol. Plantarum (Cph.) 18, 703-724 (1965)
Kaufman, P.B.: Role of gibberellins in the control of intercalary growth and cellular differentiation in developing Avena internodes. Ann. N.Y. Acad. Sci. 144, 191-203 (1967)

Maeda, E.: The effects of growth regulators on the geotropism of the leaf sheath basal region in wheat. J. exp. Bot. 9, 343-349 (1958)

Maeda, E.: Geotropic reaction of excised rice leaves. Physiol. Plantarum (Cph.) 13, 204-213 (1960)

Majumdar, G.P., Preston, R.D.: The fine structure of collenchyma cells in Heracleum sphondylium L. Proc. roy. Soc. B 130, 201217 (1942)

Preston, R.D., Duckworth, R.B.: The fine structure of the cell walls of collenchyma cells in Petasites vulgaris L. Proc. Leeds Philos. Soc. 4, 343-351 (1946)

Roland, J.C.: Organization de la membrane paraplasmique du collenchyme. J. Microscopy 5, 323-348 (1966)

Sachs, J.: Lectures on the physiology of plants. [Engl. transln.] Oxford: Clarendon Press 1887

Wardrop, A.B. : The structure of the cell wall in lignified collenchyma of Eryngium sp. (Umbelliferae). Aust. J. Bot. 17, 229-240 (1969)

Received 1 March; accepted 12 April 1976 